\title{
The Development Impact of PT. Medco E \& P Malaka on Economic Aspects in East Aceh Regency
}

\author{
Mirza Mardhan Shah ${ }^{1}$, Sirojuzilam², Linda T Maas ${ }^{2}$ \\ ${ }^{1}$ Master Student in Universitas Sumatera Utara, Medan, Indonesia \\ ${ }^{2}$ Lecturer in Universitas Sumatera Utara, Medan, Indonesia \\ Mirza.mar@gmail.com
}

\begin{abstract}
Development basically aims to realize prosperity for the community. Development can be done by implementing in various forms of programs. Development that uses human resources and high technology to process natural resources that can be utilized for human life, one of which is the development of oil and gas exploration block A area of PT. Medco E \& P Malaka in Indra Makmur Sub-district. This activity is expected to provide positive benefits for the welfare of the people around the exploration activities. The type of research is associative research with a quantitative approach. This research was conducted in the oil and gas exploration area of Block A Area PT. Medco E \& P Malaka in Alue Ie Itam and Blang Nisam Villages in Indra Makmur Sub-district, East Aceh Regency. Respondents in the study consisted of 50 respondents. The result of this study is the economic impact of oil and gas exploration development in Block $A$ area of PT. Medco E \& $P$ Malaka has a very positive impact on income, home ownership, home conditions, and additional income of the community in Alue Ie Itam Village and Blang Nisam Village. This can be seen from tcount (6.852) which is greater than ttable (1.67591). Significant differences are also indicated by the significance score $(0.00<0.05)$.
\end{abstract}

Keywords

development

impact; PT.Medco

E\&P Malaka;

economic aspect

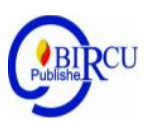

\section{Introduction}

Development is a systematic and continuous effort made to realize something that is aspired. Development is a change towards improvement. Changes towards improvement require the mobilization of all human resources and reason to realize what is aspired. In addition, development is also very dependent on the availability of natural resource wealth. The availability of natural resources is one of the keys to economic growth in an area. The relationship between inflation and economic growth is one of the debatable issue and the most important macroeconomic discussions among macro economists, policy-makers and monetary authorities in all countries (Wollie, 2018). Therefore the availability of natural resources must be managed and utilized by the government and the community appropriately, which can provide optimal benefits for the continuity of nature and humans in the future.

Development basically aims to realize prosperity for the community. Development can be done by implementing in various forms of programs. Development that uses human resources and high technology to process natural resources that can be utilized for human life, one of which is the development of oil and gas exploration block A area of PT. Medco E \& P Malaka in Indra Makmur Sub-district. This activity is expected to provide positive benefits for the welfare of the people around the exploration activities.

PT. Medco Energi Internasional Tbk, through PT Medco E \& P Malaka together with its partners Kris Energi and Japex, inaugurated the start of the development of the block A 
gas field in Indra Makmur Sub-district, East Aceh Regency on November 23, 2015. The company has actually been managing the block A field since early 2007 and has made various commercial and technical efforts to realize the development of several gas fields in block A, namely Alur Siwah, Julok Rayeuk and Alur Rambong fields. The progress of the Block A field development project was marked by the signing of the gas buying and selling (PJBG) in January 2015 and the selection of a consortium of PT Encona Inti Industri and PT. JGC Indonesia as the executor of the development of Block A production facilities.

The location of oil and gas exploration block A area of PT. Medco E \& P Malaka is located in Blang Nisam Village, Indra Makmur Sub-district. There are three fields targeted to start its first production. The three fields are Alur Siwah, Alur Rambong and Julok Rayeuk fields. The first production begins in early 2018 to meet the supply of 63 billion British thermal units per day (BBTUD), which will be channeled into the Pertamina Arun Belawan pipeline distribution system, to support the continuity of fertilizer and electricity factories and industries in Aceh. PT. Medco E \& P Malaka is a cooperation contract contractor (KKKS) working on state-owned upstream oil and gas projects.

\section{Review of Literature}

\subsection{Definition of Development}

Rogers in Nasution (2004) states that development is a process of social change with broad participation in a society, which is intended for social and material progress (including increasing the amount of justice, freedom and other scored qualities) for the majority of the people through more control the amount they get for their environment.

Siagian (1994) provides an understanding of development as "A business or series of efforts for growth and change that are planned and carried out consciously by a nation, state and government, towards modernity in the context of fostering the nation (nation building)". Meanwhile, according to Ginanjar Kartasasmita (1994), development is a process of change for the better through planned efforts.

\subsection{Impact}

Impact can be interpreted simply is a change that occurs due to an activity. These activities can be natural, both social, economic, physical, chemical and biological. According to the KBBI the impact is a collision, an effect which brings about both positive and negative impacts. Influence is the power that exists and arises from something (people, things) that helps shape a person's character, beliefs or deeds. Influence is a situation where there is a reciprocal relationship or causal relationship between what influences what is affected. Impacts have the following effects:

a. Positive impact is the impact that has a positive effect.

b. Negative impacts are impacts that have a negative effect.

c. Direct impacts are impacts that are felt directly and are related to positive impacts.

d. Indirect impacts are indirect impacts that are felt by an influence (KBBI in Sartika, 2014)

So, from the definition above regarding the impact of exploration development in the oil and gas industry block A area of PT. Medco E \& P Malaka towards regional development has changed. The impact here is the economic, social, and environmental aspects. Environmental impacts are changes in terms of village management, development of roads for transportation facilities, water and air conditions of the mosque as a means of 
worship, and schools as a means of education. The social impact is the shifting mindset and productivity of the people who previously planted and switched to other jobs. While the impact on the economic aspect, there is a change in income due to the development of other businesses in the local community.

\subsection{Economic Aspects}

Income is the work of business and so on, finding a discovery about something that did not exist before, according to the KBBI, income is defined as the result of work or business in the form of money or goods as a form of income is wages or salaries, which means money paid in retaliation services or as labor payers that have been issued to do something (Ministry of Education and Culture RI, 1995).

Income is the amount received usually within a certain period of time is usually one year, community income is thus all receipts received in a particular year either from industry, trade and other sectors. The economic condition of the population is a condition that describes human life that has economic score. Economic conditions are assessed through three variables: livelihoods, income, and ownership of valuables.

\section{Research Method}

The type of research is associative research with a quantitative approach. According to Sugiyono (2008), associative research is research that aims to determine the effect or relationship between the independent variable and the dependent variable and how closely the two are related. According to Sugiyono (2003), quantitative research is research by obtaining data in the form of numerical data or qualitative data.

The map of the research location is in the following figure:

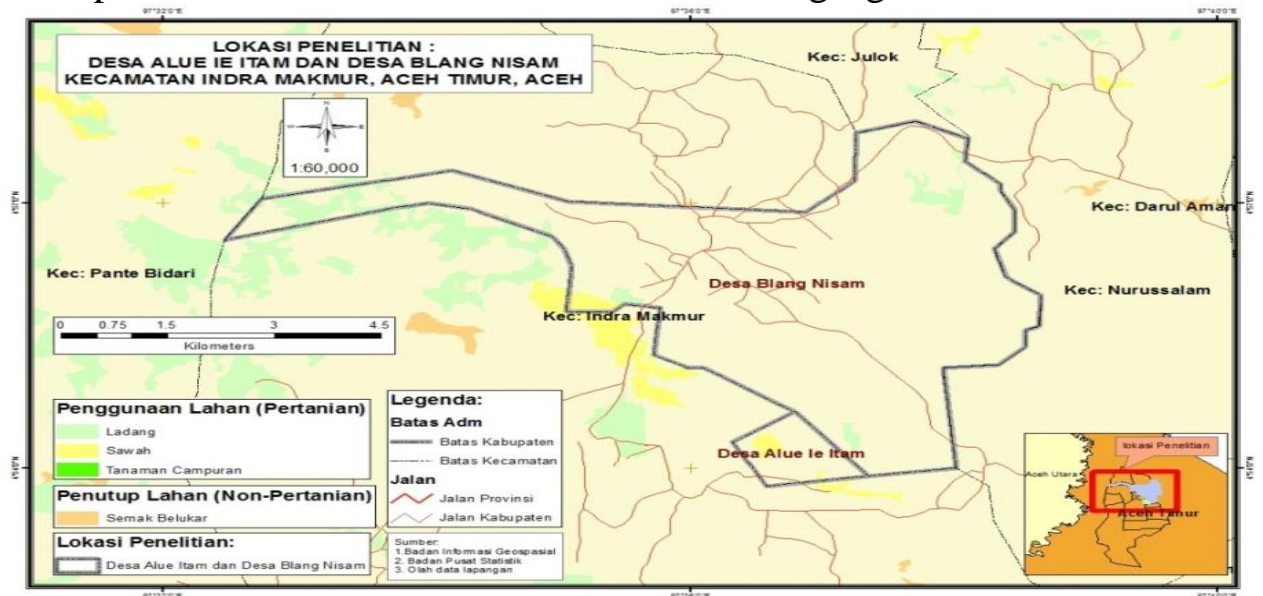

Source: Data processed, 2019

Figure 1. Research Location Map

This research was conducted in the oil and gas exploration area of Block A Area PT. Medco E \& P Malaka in Alue Ie Itam and Blang Nisam Villages in Indra Makmur Sub-district, East Aceh Regency based on the consideration that the Indra Makmur Subdistrict was the place affected by the development of Oil and Gas Exploration with an area of $89.05 \mathrm{Km}^{2}$. 


\section{Discussion}

Respondents in the study consisted of 50 respondents in Alue Ie Itam Village and Blang Nisam Village. To be more clear, the number of respondents by cluster and gender can be seen in Table 1. below:

Table 1. Number of Respondents Based on Village and Gender

\begin{tabular}{|c|c|c|c|c|c|c|c|}
\hline \multirow[b]{2}{*}{ No } & \multirow[b]{2}{*}{ Name of Village } & \multicolumn{2}{|c|}{ Male } & \multicolumn{2}{|c|}{ Female } & \multicolumn{2}{|c|}{ Total } \\
\hline & & $\begin{array}{c}\text { Total } \\
\text { (Person) }\end{array}$ & $\%$ & $\begin{array}{c}\text { Total } \\
\text { (Person) }\end{array}$ & $\%$ & $\begin{array}{c}\text { Total } \\
\text { (Person) }\end{array}$ & $\%$ \\
\hline 1. & Alue Ie Itam & 28 & $56 \%$ & - & $0 \%$ & 28 & $56 \%$ \\
\hline 2. & Blang Nisam & 20 & $40 \%$ & 2 & $4 \%$ & 22 & $44 \%$ \\
\hline & Total & 48 & $96 \%$ & 2 & $4 \%$ & 50 & $100 \%$ \\
\hline
\end{tabular}

Source: Primary Data, 2019

The data in Table 1. shows that the most respondents came from Alue Ie Itam, with 28 people $(56 \%)$ who were all male. Followed by respondents who came from Blang Nisam whose respondents were 20 men (40\%) and 2 women (4\%). This is natural because men are responsible for providing family income. The number of respondents by age group can be seen in the table below:

Table 2. Number of Respendents Based on Age Group

\begin{tabular}{|l|c|c|c|}
\hline No & Age Group & Total(Person) & \% \\
\hline 1. & $21-30$ & 8 & $16 \%$ \\
\hline 2. & $31-40$ & 15 & $30 \%$ \\
\hline 3. & $41-50$ & 27 & $54 \%$ \\
\hline \multicolumn{2}{|c|}{ Total } & 50 & $100 \%$ \\
\hline
\end{tabular}

Data Sources: Primary Data, 2019

The data in Table 2. above shows that respondents were dominated by respondents with an age group of 41-50 years, namely a number of 27 people (54\%), then respondents with an age group 31-40 years amounted to 15 people (30\%), and respondents with a group aged 21-30 years amounted to 8 people (16\%). The number of respondents based on ethnicity (ethnicity) can be seen in the table below:

Table 3. Number of Respondents Based on Ethnicity

\begin{tabular}{|l|c|c|c|}
\hline No & Ethnicity & Total(Person) & $\%$ \\
\hline 1. & Aceh & 29 & $58 \%$ \\
\hline 2. & Jawa & 21 & $42 \%$ \\
\hline \multicolumn{2}{|c|}{ Total } & 50 & $100 \%$ \\
\hline
\end{tabular}

Data Sources: Primary Data, 2019

In Table 3. above shows that most respondents in Acehnese ethnic research, namely as many as 29 people (58\%), while Javanese respondents totaled 21 people (42\%). The number of respondents based on their level of education can be seen in the table below: 
Table 4. Number of Respondents Based on Education Level

\begin{tabular}{|c|l|c|c|}
\hline No & \multicolumn{1}{|c|}{ Education } & Total(Person) & \% \\
\hline 1. & Did not undergo education & 3 & $6 \%$ \\
\hline 2. & Elementary School & 9 & $18 \%$ \\
\hline 3. & Junior High School & 11 & $22 \%$ \\
\hline 4. & Senior High School & 26 & $52 \%$ \\
\hline 5. & Diploma/Degree & 1 & $1 \%$ \\
\hline \multicolumn{2}{|c|}{ Total } & 50 & $100 \%$ \\
\hline
\end{tabular}

Data Sources: Primary Data, 2019

Based on the data in Table 4. above it is known that 3 people $(6 \%)$ respondents of the study did not undergo education, 9 people $(18 \%)$ had elementary school education, 11 people $(22 \%)$ had junior high school education, 26 people $(52 \%)$ had senior school education, and 1 Diploma / Degree educated person. Development of oil and gas exploration in the Block A area of PT. Medco E \& P Malaka has significantly increased the productivity of the surrounding communities in Alue Ie Itam Village and Blang Nisam Village. The results of the different main income test of the people of Alue Ie Itam Village and Blang Nisam Village before and after the development of PT. Medco E \& P Malaka can be seen in Table 5. Below:

Table 5. Descriptive Statistic Analysis Test of Main Income Before and After the Development of PT. Medco E \& P Malaka Paired Samples Statistics

\begin{tabular}{llcccc}
\hline & & Mean & N & Std. Deviation & Std. Error Mean \\
\hline Pair 1 & After (Primary Income) & 2960706,40 & 50 & 2082563,286 & 294518,924 \\
& Before (Primary Income) & 2188000,00 & 50 & 1996184,115 & 282303,065 \\
\cline { 2 - 6 }
\end{tabular}

Data Sources: Data Processed, 2019

In Table 5. it can be seen:

a. The average income of the people of Alue Ie Itam Village and Blang Nisam Village before the development of PT. Medco E \& P Malaka is Rp. 2,188,000.00, - with a standard deviation of 1,996,184.115 and a mean standard error of 282,303,065.

b. The average income of the people of Alue Ie Itam Village and Blang Nisam Village after the development of PT. Medco E \& P Malaka is Rp. 2,960,706.40, - with a standard deviation of 2,082,563,286 and a mean standard error of 294,518,924.

Table 6. Difference Test Results of Main Income Before and After Exploration

Development of PT. Medco E \& P Malaka

\begin{tabular}{lr}
\hline Description & Income \\
\hline Number of Samples (KK) & 50 \\
Average Main Income Before Development & Rp. $2.188 .000,00,-$ \\
Average Main Income After Development & Rp. 2.960.706,40,-- \\
Significance & 0,00 \\
$\mathrm{~T}_{\text {count }}$ & 6,852 \\
$\mathrm{t}_{\text {table }}$ & 1,67591 \\
Information* $: \alpha=0,05$ & \\
\hline
\end{tabular}

Data Sources: Data Processed, 2019 
From Table 6. it can be seen that there are significant differences between the average main income of the people of Alue Ie Itam Village and Blang Nisam Village before and after the development of oil and gas exploration in the Block A area of PT. Medco E \& P Malaka. This can be seen from the $t_{\text {count }}(6.852)$ which is greater than $t_{\text {table }}$ (1.67591). Significant differences are also indicated by the significance score $(0.00<0.05)$. Thus the hypothesis which states that there are positive and significant differences between the main income before and after the development of oil and gas exploration in the Block A area of PT. Medco E \& P Malaka. The results of research on the additional income of the people of Alue Ie Itam Village and Blang Nisam Village are as follows:

Table 7. Descriptive Statistical Analysis Test of Additional Income Before and After the Development of PT. Medco E \& P Malaka

Paired Samples Statistics

\begin{tabular}{clcccc}
\hline & & Mean & N & Std. Deviation & Std. Error Mean \\
\hline \multirow{2}{*}{ Pair 1 } & After (Additional Income) & 2141830,00 & 50 & 2073202,159 & 293195,061 \\
& Before (Additional Income) & 938000,00 & 50 & 1651825,212 & 233603,362 \\
\cline { 2 - 6 }
\end{tabular}

Data Sources: Data Processed, 2019

In Table 7. it can be seen:

a. The average income of the people of Alue Ie Itam Village and Blang Nisam Village before the development of PT. Medco E \& P Malaka is Rp. 938,000.00 with a standard deviation of 1,651,825,212 and a mean standard error of 233,603,362.

b. The average score of additional income for the people of Alue Ie Itam Village and Blang Nisam Village after the development of PT. Medco E \& P Malaka is Rp. $2,141,830.00$, - with a standard deviation of 2,073,202,159 and a mean standard error of $293,195,061$.

Table 8. Difference Test Results for Additional Income Before and After the Development of PT. Medco E \& P Malaka

\begin{tabular}{|c|c|}
\hline Description & Income \\
\hline Number of Samples (KK) & 50 \\
\hline Average Additional Income Before Development & Rp. $938.000,-$ \\
\hline Average Additional Income After Development & Rp. 2.141.830,- \\
\hline Significance & 0,00 \\
\hline $\mathrm{T}_{\text {count }}$ & 7,307 \\
\hline $\begin{array}{l}\mathrm{t}_{\text {table }} \\
\text { Information } *: \alpha=0,05\end{array}$ & 1,67591 \\
\hline
\end{tabular}

Data Sources: Data Processed, 2019

From Table 8. it can be seen that there are significant differences between the average additional income of the people of Alue Ie Itam Village and Blang Nisam Village before and after the development of oil and gas exploration in the Block A area of PT. Medco E \& P Malaka. This can be seen from the score of $t_{\text {count }}(7.307)$ which is greater than $t_{\text {table }}(1.67591)$. Significant differences are also indicated by the significance score $(0.00<0.05)$. Thus the hypothesis which states that there are positive and significant differences between income before and after the development of oil and gas exploration in the Block A area of PT. Medco E \& P Malaka .

Increased income in Alue Ie Itam Village and Blang Nisam Village before and after the development of PT. Medco E \& P Malaka can be caused by several things: 
a. Development of PT. Medco E \& P Malaka led to an increase in the income of the people of Alue Ie Itam Village and Blang Nisam Village, it can be concluded because the increase in population is directly proportional to the purchasing power of the community.

b. Development of PT. Medco E \& P Malaka caused an increase in the income of the people of Alue Ie Itam Village and Blang Nisam Village, it can be concluded because PT. Medco E \& P Malaka provided counseling on the empowerment of compost, honey bees, fitness drinks, etc. which resulted in the growth of new businesses that had an impact on increasing the income of the people of Alue Ie Itam Village and Blang Nisam Village.

Table 9. Respondents' Answers About Home Ownership Before and After the Development of PT. Medco E \& P Malaka

\begin{tabular}{|l|l|c|c|c|c|}
\hline \multirow{2}{*}{ No } & \multicolumn{2}{|c|}{ Ownership status } & \multicolumn{2}{c|}{ Before } & \multicolumn{2}{c|}{ After } \\
\cline { 3 - 6 } & $\begin{array}{c}\text { Total } \\
\text { (Person) }\end{array}$ & $\%$ & $\begin{array}{c}\text { Total } \\
\text { (Person) }\end{array}$ & $\%$ \\
\hline 1. & One's own & 36 & $72 \%$ & 47 & $94 \%$ \\
\hline 2. & Rent & 10 & $20 \%$ & 1 & $2 \%$ \\
\hline 3. & Ride with Parents & 3 & $6 \%$ & 2 & $4 \%$ \\
\hline 4. & Ride with Other People & 0 & $0 \%$ & 0 & $0 \%$ \\
\hline 5. & Others & 1 & $2 \%$ & 0 & $0 \%$ \\
\hline \multicolumn{2}{|c|}{ Total } & 50 & $100 \%$ & 50 & $100 \%$ \\
\hline
\end{tabular}

Data Sources: Primary Data, 2019

The data in Table 9. can be seen a comparison of the status of home ownership before and after the development of oil and gas exploration in the Block A area of PT. Medco E \& P Malaka and it can be concluded that the ownership status of own-owned houses has increased from 36 heads of households (72\%) to 47 heads of households (94\%), heads of households who contracted houses that used to have 10 households $(20 \%)$ decreased only 1 heads of households $(2 \%)$. The different test results ( $t$ test) against the comparison of the status of home ownership before and after the development of PT. Medco E \& P Malaka is as follows:

Table 10. Statistical Analysis Test About Home Ownership Before and After the Development of PT. Medco E \& P Malaka

Paired Samples Statistics

\begin{tabular}{llrrrr}
\hline & & Mean & N & Std. Deviation & Std. Error Mean \\
\hline Pair 1 & After (Home Ownership) & 4,90 & 50 &, 416 &, 059 \\
& Before (Home Ownership) & 4,46 & 50 &, 952 &, 135 \\
\cline { 2 - 6 }
\end{tabular}

Data Sources: Data Processed, 2019

In Table 10. it can be seen:

a. The average score of the ownership status of community houses in Alue Ie Itam Village and Blang Nisam Village prior to the development of PT. Medco E \& P Malaka is 4.46 with a standard deviation of 0.952 and a mean standard error of 0.135 .

b. The average score of the ownership status of community houses in Alue Ie Itam Village and Blang Nisam Village after the development of PT. Medco E \& P Malaka is 4.90 with a standard deviation of 0.416 and a mean standard error of 0.059 . 
Table 11. Different Test Results of Ownership Status Before and After the Development of PT. Medco E \& P Malaka

\begin{tabular}{lr}
\hline \multicolumn{1}{c}{ Description } & \multicolumn{1}{c}{ Score } \\
\hline Number of Samples (KK) & 50 \\
Average Home Ownership Before Construction & 4,46 \\
Average Home Ownership after Construction & 4,90 \\
Significance & 0,001 \\
$\mathrm{~T}_{\text {count }}$ & 3,518 \\
$\mathrm{t}_{\text {table }}$ & 1,67591 \\
Information* $: \alpha=0,05$ & \\
\hline
\end{tabular}

Data Sources: Data Processed, 2019

From Table 11. it can be seen that there are significant differences in the ownership status of community houses in Alue Ie Itam Village and Blang Nisam Village before and after the development of PT. Medco E \& P Malaka. This can be seen from the score of $t_{\text {count }}(3.518)$ which is greater than $t_{\text {table }}(1.67591)$. Significant differences are also indicated by the significance score $(0.001<0.05)$. Thus the hypothesis which states that there is a positive and significant difference between the status of home ownership before and after the development of oil and gas exploration Block A area of PT. Medco E \& P Malaka .

In addition, a comparison of the status of home ownership, follows the data on the condition of the house before and after the development of Oil and Gas Exploration Area Block A of PT Medco E \& P Malaka in Blang Nisam Village and Alue Ie Itam Village:

Table 12. Respondents' Answers About the Condition of the House Before and After the Development of PT. Medco E \& P Malaka

\begin{tabular}{|l|l|c|c|c|c|}
\hline \multirow{2}{*}{ No } & \multicolumn{2}{|c|}{ House Conditions } & \multicolumn{2}{|c|}{ Before } & \multicolumn{2}{c|}{ After } \\
\cline { 3 - 6 } & & $\begin{array}{c}\text { Total } \\
\text { (Person) }\end{array}$ & $\%$ & $\begin{array}{c}\text { Total } \\
\text { (Person) }\end{array}$ & $\%$ \\
\hline 1. & Permanent & 8 & $16 \%$ & 27 & $54 \%$ \\
\hline 2. & Semi-permanent & 19 & $38 \%$ & 16 & $32 \%$ \\
\hline 3. & Board & 22 & $44 \%$ & 7 & $14 \%$ \\
\hline 4. & Bamboo / Tepas & 1 & $2 \%$ & 0 & $0 \%$ \\
\hline 5. & Other, please specify & 0 & $0 \%$ & 0 & $0 \%$ \\
\hline \multicolumn{2}{|c|}{ Total } & 50 & $100 \%$ & 50 & $100 \%$ \\
\hline
\end{tabular}

Data Sources: Primary Data, 2019

Table 13. Statistical Analysis Test About the Condition of the House Before and After the Development of PT. Medco E \& P Malaka

Paired Samples Statistics

\begin{tabular}{llcccc}
\hline & & Mean & $\mathrm{N}$ & Std. Deviation & Std. Error Mean \\
\hline Pair 1 & After (House Conditions) & 4.44 & 50 & .675 & .095 \\
& Before (House Conditions) & 3.68 & 50 & .768 & .109 \\
\cline { 2 - 6 }
\end{tabular}

Data Sources: Data Processed, 2019

The different test results ( $t$ test) against a comparison of the status of the condition of the house before and after the development of PT. Medco E \& P Malaka in Table 13. above can be known: 
a. The average score of the housing conditions of the people of Alue Ie Itam Village and Blang Nisam Village prior to the development of PT. Medco E \& P Malaka is 3.68 with a standard deviation of 0.768 and a mean standard error of 0.109 .

b. The average score of the housing conditions of the people of Alue Ie Itam Village and Blang Nisam Village after the development of PT. Medco E \& P Malaka is 4.44 with a standard deviation of 0.675 and a mean standard error of 0.095 .

Table 14. Different Test Results of House Conditions Before and After the Development of PT. Medco E \& P Malaka

\begin{tabular}{lr}
\hline \multicolumn{1}{c}{ Description } & \multicolumn{1}{c}{ Score } \\
\hline Number of Samples (KK) & 50 \\
Average House Condition Before Construction & 3,68 \\
Average Condition of Houses after Construction & 4,44 \\
Significance & 0,001 \\
$\mathrm{~T}_{\text {count }}$ & 9,092 \\
$\mathrm{t}_{\text {table }}$ & 1,67591 \\
Information $*: \alpha=0,05$ & \\
\hline Data Sources: Data Processed, 2019
\end{tabular}

Development of oil and gas exploration in the Block A area of PT. Medco E \& P Malaka has significantly increased the productivity of the surrounding communities in Alue Ie Itam Village and Blang Nisam Village. The results of the different main income test of the people of Alue Ie Itam Village and Blang Nisam Village before and after the development of PT. Medco E \& P Malaka can be seen that there is a significant difference between the average main income of the people of Alue Ie Itam Village and Blang Nisam Village before and after the development of oil and gas exploration in the Block A area of PT. Medco E \& P Malaka. This can be seen from the score of $t_{\text {count }}(6.852)$ which is greater than $t_{\text {table }}(1.67591)$. Significant differences are also indicated by the significance score $(0.00<0.05)$. Thus, it can be concluded that there is a positive and significant impact on the main income of the people of Alue Ie Itam Village and Blang Nisam Village before and after the development of oil and gas exploration in the Block A area of PT. Medco E \& P Malaka.

The results of research on the additional income of the people of Alue Ie Itam Village and Blang Nisam Village can be seen that there are significant differences between the average side income of the people of Alue Ie Itam Village and Blang Nisam Village before and after the development of oil and gas exploration in the Block A area of PT. Medco E \& P Malaka. This can be seen from the score of $t_{\text {count }}$ (7.307) which is greater than $t_{\text {table }}(1.67591)$. Significant differences are also indicated by the significance score $(0.00<0.05)$. Thus, it can be concluded that there is a positive and significant impact on the additional income of the people of Alue Ie Itam Village and Blang Nisam Village before and after the development of oil and gas exploration in the Block A area of PT. Medco E \& P Malaka .

Increased income in Alue Ie Itam Village and Blang Nisam Village before and after the development of PT. Medco E \& P Malaka can be caused by several things:

a. The development of PT. Medco E \& P Malaka led to an increase in the income of the people of Alue Ie Itam Village and Blang Nisam Village, it can be concluded because the increase in population is directly proportional to the purchasing power of the community. 
b. The development of PT. Medco E \& P Malaka caused an increase in the income of the people of Alue Ie Itam Village and Blang Nisam Village, it can be concluded because PT. Medco E \& P Malaka provided counseling on the empowerment of organic liquid fertilizer and compost, honey bees, fitness drinks, etc. which resulted in the growth of new businesses that had an impact on increasing the income of the people of Alue Ie Itam Village and Blang Nisam Village. After a different test ( $t$ test) for 50 samples in Alue Ie Itam Village and Blang Nisam Village, it can be seen that there are significant differences regarding the ownership status of the houses of the Alue Ie Itam Village and Blang Nisam Village before and after the development of PT. Medco E \& P Malaka. This can be seen from the score of $t_{\text {count }}$ (3.518) which is greater than $t_{\text {table }}$ (1.67591). Significant differences are also indicated by the significance score $(0.001$ $<0.05)$. Thus it can be concluded that there is a positive and significant impact on the status of home ownership before and after the development of oil and gas exploration in the Block A area of PT. Medco E \& P Malaka .

c. The different test results ( $t$ test) against the comparison of the status of home ownership before and after the development of PT. Medco E \& P Malaka can be seen that there are real differences about the condition of the houses of the Alue Ie Itam Village and Blang Nisam Village before and after the development of PT. Medco E \& $P$ Malaka. This can be seen from the score of $t_{\text {count }}(9.092)$ which is greater than $t_{\text {table }}$ (1.67591). Significant differences are also indicated by the significance score $(0,000$ $<0.05)$. Thus it can be concluded that there are positive and significant impacts on the condition of houses before and after the development of oil and gas exploration in the Block A area of PT. Medco E \& P Malaka.

\section{Conclusion}

The economic impact of oil and gas exploration development in Block A area of PT. Medco E \& P Malaka has a very positive impact on income, home ownership, home conditions, and additional income of the community in Alue Ie Itam Village and Blang Nisam Village. This can be seen from $t_{\text {count }}(6.852)$ which is greater than $t_{\text {table }}(1.67591)$. Significant differences are also indicated by the significance score $(0.00<0.05)$.

\section{References}

Akil, S. (2001). Penataan Ruang dalam Rangka Mendorong Pengembangan Ekonomi Wilayah. Tangerang.

Afifuddin, (2012), Pengantar Administrasi Pembangunan (konsep,teori, dan implikasinya di era revormasi, Bandung, Alfabeta.

Azwar, S. (1995). Sikap Manusia Teori dan Pengukurannya. Pustaka Pelajar, Yogyakarta. [BPS dan Bappeda], (2018)Kabupaten Aceh Timur dalam angka. Kabupaten Aceh Timur.

Bishop, C.E. and W.D Toussaint. (1979). Pengantar Analisa Ekonomi Pertanian. Mutiara Sumber Widya, Jakarta.

Departemen Pendidikan dan Kebudayaan. (1995). Kamus Besar Bahasa Indonesia. Jakarta : Balai Pustaka.

Ferdinand, Augusty. (2014). Metode Penelitian Manajemen. BP Universitas Diponegoro. Semarang.

Ginandjar Kartasasmita, (1994). Pembangunan yang berkesinambungan dan berkeadilan dalam PJP II / Malang Universitas Brawijaya 
Hermansyur. (1996). Analisa Pengembangan Wilayah Kecamatan pada Beberapa Koridor Medan. Medan.

Jayadinata, T. Johara (1999). Tata Guna Tanah dalam Perencanaan Pedesaan Perkotaan dan Wilayah. Institut Teknologi Bandung.

Maryatmo and Susilo. (1996). Dari Masalah Usaha Kecil sampai Masalah Ekonomi Makro. Universitas Atmajaya, Yogyakarta.

Mulyanto Sumardi. (1985). Sumber Pendapatan Kebutuhan Pokok dan Perilaku Menyimpang. CV. Rajawali. Jakarta

Narwoko, J. Dwi and Suyanto. (2007). Sosiologi Teks Pengantar dan Terapan. Jakarta : Prenada Media Group

Nasution, Z. (2004). komunikasi Pembangunan pengenalan teori dan penerapannya Jakarta: Rajawali Pers.

Sugiyono. (2003). Metode Penelitian Bisnis. Penerbit Alfabeta, Bandung.

Sugiono. (2008). Metode Penelitian Administrasi. Penerbit Alfabeta, Bandung.

Sirojuzilam. (2016). Pembangunan Ekonomi Regional. USU Press, Medan.

Soerjono, Soekanto. (2006). Sosiologi Suatu Pengantar. Jakarta : Raja Grafindo.

Suratmo, F.G. (1982). Ilmu Perlindungan Hutan.Bogor:Fak Kehutanan, IPB.

Tambun, M.U. Firman. (1992). Perencanaan Transportasi dengan Pendekatan Pengembangan Wilayah. Seminat Tahun II Alumni Jurusan Sipil FT. USU Medan.

Todaro, Michael. P, (1989). Pembangunan Ekonomi di Dunia Ketiga. Jakarta : PT Erlangga (Terjemahan).

Tarigan, Robinson. (2010). Perencanaan Wilayah Edisi Revisi. PT Bumi Aksara, Jakarta.

[USU] Universitas Sumatera Utara, sekolah Pascasarjana. (2018). Pedoman Penulisan Tesis Dan Disertasi. USU PPs, Medan.

Wahyunto, (2001), Studi Perubahan Lahan di Sub Das Citarik, Jawa Barat dan Kali Garang Jawa Tengah. Prosiding Seminar Nasional Multif

Winarto, Budi. (2012). Kebijakan Publik Teori, Proses dan Studi Kasus. Caps, Yogyakarta.

Wollie, G. (2018). The Relationship between Inflation and Economic Growth in Ethiopia. Budapest International Research and Critics Institute (BIRCI-Journal), 264-271.

Zamzami Ali. (2019). Kualitas Udara Blok A dipaparkan di DPRK. https://klikkabar.com/2019/07/18/kualitas-udara-blok-a-dipaparkan-di-dprk/. Diakses tanggal 06/11/2019 jam 15:32. 